\title{
破砕産物の粒度分布特性*
}

岩石爆破の基礎的研究

$\begin{array}{llllll}\text { 大 } & \text { 塚 } & \text { 雄 }^{1} & \text { 宮 } & \text { 腰 } & \text { 宏 }^{2} \\ \text { 佐 } & \text { 藤 } & \text { 博 }^{3} & \text { 佐 } & \text { 藤 } & \text { 勇 }^{4} \\ \text { 岩 } & \text { 井 } & \text { 肇 }^{5} & & & \end{array}$

1. はしがき

発破にあたつては，使用される爆薬の力を有効に利用し， 破砕産物ができるだけ希望する粒径の破片で構成され，飛 散も少なく, その後の付帯作業に消費される労力が最小で すむようにすることが大切である。

筆者らは, これまでセメントモルタルや岩石を整形して 作つた小型の供試体を用い, 爆薬なしに雷管だけを起爆さ せて, 得られた漏斗孔の形状や寸法などを測定し, 実験室 で比較的容易に測定できる供試体の力学的特性値, たとえ ば,一軸圧縮強度, 圧裂引張強度, 弾性波伝播速度, 静的 ヤング率, ポアソン比および動的ヤング率, ポアソン比と の相関性をしらべ, その結果を数回にわたつて報告してき た。

今回, セメントモルタルで作つた一定の大きさの供試体 に一定量の爆薬を装薬深度を変えて装てんして起爆させた 場合 ( シリーズ 1 ) と大きさが異なる $2 ， 3$ の供試体の中 心でそれぞれ異なる量の爆薬を起爆させた場合 ( シリーズ 2 ）に得られた破砕産物の粒度分布に着目し, 適合する粒 度分布関数を見いだし, 破砕産物全体の平均粒径, 比表面 積などを計算し，それを用いて爆破条件の相異が破砕産物 の粒度特性にどのように影響するかを知り，それらの相互 の関係を明らかにしようとして実験した。

\section{2. 実験に用いた供試体と実験の方法}

\section{$2 \cdot 1$ 実験に用いた供試体}

できるだけ等方, 均質で, 製作にあたつて, 必要な場合 は, その大きさを自由に変えて作れるように, 供試体をセ

第1表 モルタル試料作製基準

\begin{tabular}{|c|c|}
\hline $\begin{array}{l}\text { セメント } \\
\text { 細骨材. }\end{array}$ & $\begin{array}{l}\text { ポルトランドセメント } \\
\text { 標準砂 (山口県豊浦産) }\end{array}$ \\
\hline 水一セxント比 & $55 \%$ \\
\hline 自然乾燥期間 & 24 時間 \\
\hline 鉝生期間 & １4 日間 \\
\hline 材令 & 150 日以上 \\
\hline セメ゙ント：骨材 & $1: 1$ \\
\hline
\end{tabular}

* 1980 年 5 月 28 日受理

1. 正会員工博 秋田大学教授 鉱山学部採鉱学科

2. 正会員 秋田大学助教授 鉱山学部採鉱学科

3. 正会員 秋田大学講師 鉱山学部採鉱学科

4. 正会員 秋田大学鉱山学部採鈗学科

5. 学生会員 秋田大学大学院修士課程 (現)三井石炭鉱業株式 会社・
メント，モルタルで作つた。本実験での作製基準は第 1 表 に示された通りである。

供試体は立方体で，その大きさは一辺が $250 \mathrm{~mm}, 198$ $\mathrm{mm}, 157 \mathrm{~mm}$ 抢よび $125 \mathrm{~m}$ とし, 最大寸法のものを基準 にして，それぞれの体積は $1 / 2 ， 1 / 4$ ，および $1 / 8$ になる ようにした。

供試体の力学的な特性值, 比重および空吵率は第 2 表に 一括して示した。

\section{$2 \cdot 2$ 実験の方法}

実験にあたつて, 一定の薬量を深度を変えて装薬して起 爆させる場合は, 辺長が $250 \mathrm{~mm}$ の最大寸法の供試体を用 い，供試体の一つの面の中央に深さが，それぞれ，125 mm， $100 \mathrm{~mm}, 75 \mathrm{~mm}, 50 \mathrm{~mm}$ および $25 \mathrm{~mm}$ の装薬孔を作り， 三号桐ダイナマイト $8 \mathrm{~g}$ ずつを装てんし, 六号雷管で起爆 させた。

異なる薬量を供試体の中心に装薬して起爆させる場合は， 大きさの異なる 4 種類の供試体を用い，それぞれ， $2 \mathrm{~g}, 4$ $\mathrm{g}, 6 \mathrm{~g}$ および $8 \mathrm{~g}$ の薬量を用い, 六号雷管で起爆させた。 その場合の装薬深度は, 供試体の大きさによつて, $125 \mathrm{~mm}$, $99 \mathrm{~mm}, 79 \mathrm{~mm}$ および $63 \mathrm{~mm}$ となつた。

爆破した供試体の数は, 大きさ一定の供試体で装薬深度 を変えた場合は，それぞれ 3 個の供試体で，装薬量と供試 体の大きさが変わつた場合は,同じ薬量, 同じ供試体寸法に ついてそれぞれ2 個ずつであつた。

装薬孔の直径を $7.5 \mathrm{~mm}$ としたのは, 小直径の装薬孔に すると薬長が長くなり，棒状となるため実験結果に影響が でることをおそれ，できるだけ装薬長が短かく，点状装薬 の状態になるように期待したためである。装薬後のてん塞 には、コンクリート実験用の標準砂を用いた。

第2表 供試体の諸特性値（ $S_{s}$ は小林の式による）

\begin{tabular}{|c|c|c|c|c|}
\hline 項 目 & 記号 & 平均值 & 単位 & 標隼偏差 \\
\hline 一軸厓縮強度 & $\mathrm{Sc}$ & 437 & $\mathrm{~kg} / \mathrm{cm}^{2}$ & \pm 46.3 \\
\hline 圧裂引張強度 & St & 35. 9 & $\mathrm{~kg} / \mathrm{cm}^{2}$ & \pm 3.73 \\
\hline 世ん断強度 & SB & 72. 2 & $\mathrm{~kg} / \mathrm{cm}^{2}$ & - \\
\hline ぜい性率 & Br & 12. 3 & - & - \\
\hline プロトシャャコノフ指数 & $f_{4}$ & 2. 38 & - & - \\
\hline 緹波弹性波伝幡速度 & Vp & 3. 34 & $\mathrm{~kg} / \mathrm{sec}$ & \pm 0.06 \\
\hline 横波弹性波伝幡速度 & Vs & 2. 02 & $\mathrm{~kg} / \mathrm{sec}$ & \pm 0.08 \\
\hline 静的ポアソン比 & $\mu_{\mathrm{B}}$ & 0.213 & - & \pm 0.03 \\
\hline 静的ヤング率 & Es & 1. $30 \times 10^{5}$ & $\mathrm{~kg} / \mathrm{cm}^{2}$. & $\pm 0.21 \times 10^{5}$ \\
\hline 動的ポアソン比 & $\mu_{\mathrm{d}}$ & 0.211 & - & \pm 0.05 \\
\hline 動的ヤング率 & Ed & 2. $48 \times 10^{5}$ & $\mathrm{~kg} / \mathrm{cm}^{2}$ & $\pm 0.12 \times 10^{5}$ \\
\hline 比 重 & $\rho$ & $1 \cdot 87$ & - & \pm 0.01 \\
\hline 空げき率 & $\phi$ & 23. 1 & $\%$ & \pm 0.01 \\
\hline
\end{tabular}


破砕片の粒子径が問題にされたので, 爆破によつて飛散 された破碎片が爆発室周囲で2次的に破碎されるのを防ぐ ため, 周囲にゴムを張りつけたり, 緩衝材を用いて保護し た。爆破によつて得られた破砕産物は，その粒径が比較的 粗い時は最小目開きが $10 \mathrm{~mm}$ で, 目開き間隔 $10 \mathrm{~mm}$, 最大 目開き $120 \mathrm{~mm}$ のフルイでフルイ分けを行ない，爆破によ る破砕片の粒径が細かくなつた時は, フルイの最小目開き を $4.76 \mathrm{~mm}$ まで下げた。

\section{3. 実験結果の処理}

\section{$3 \cdot 1$ 破砕産物の粒度分布特性値の計算}

破砕産物の粒度分布を何らかの分布関数であらわすこと ができ，その式から平均粒径，比表面積あるいは分布特性 を示す指数が計算できれば, 実験結果の解析や定量的な比 較に広く役立てられる。

Rosin と Rammler は, ${ }^{2)}$ 無作為に破研された石炭や鉱石 のフルイ分け粒度分布について研究し, 粒度分布関数を

$$
R\left(D_{p}\right)=100 \cdot \exp \left(-b \cdot D_{p}^{n}\right)
$$

であたえた。ここで $R\left(D_{p}\right)$ は破哗産物をフルイ分けした時, あるフルイ目 $D_{p} \mathrm{~mm}$ に抠砋積算残分重量パーセントで あり, $n$ は粒度分布指数, $b$ は粒度特性数とよばれる定数 である。nの值が大きいほど破砕産物は粗い粒度のものが

第3表 破挽産物のフルイ分け結果

\begin{tabular}{|c|c|c|c|c|}
\hline $\begin{array}{l}\text { Scre日n } \\
\text { Size (mm) }\end{array}$ & N (g) & $\operatorname{SuM} N(\mathrm{~g})$ & R $\%)$ & U $(\%)$ \\
\hline+120 & & & & \\
\hline $120 \sim 110$ & 1250 & 1250 & 4. 0 & 96.0 \\
\hline $110 \sim 100$ & & & & \\
\hline $100 \sim 90$ & & & & \\
\hline $90 \sim 80$ & 1750 & 3000 & 9.6 & 90.4 \\
\hline $80 \sim 70$ & 1430 & 4430 & $14 \cdot 2$ & 85.8 \\
\hline $70 \sim 60$ & & & & \\
\hline $60 \sim 50$ & 4880 & 9310 & 29.9. & 70.1 \\
\hline $50 \sim 40$ & 4600 & 13910 & 44. 7 & 55. 3 \\
\hline $40 \sim 30$ & 5380 & 19290 & 62. 0 & 38.0 \\
\hline$-30 \sim 20$ & 6380 & 25670 & 82.5 & $17 \cdot 5$ \\
\hline $20 \sim 10$ & 3980 & 29650 & 95.3 & 4. 7 \\
\hline-10 & 1460 & 31110 & 100.0 & 0 \\
\hline
\end{tabular}

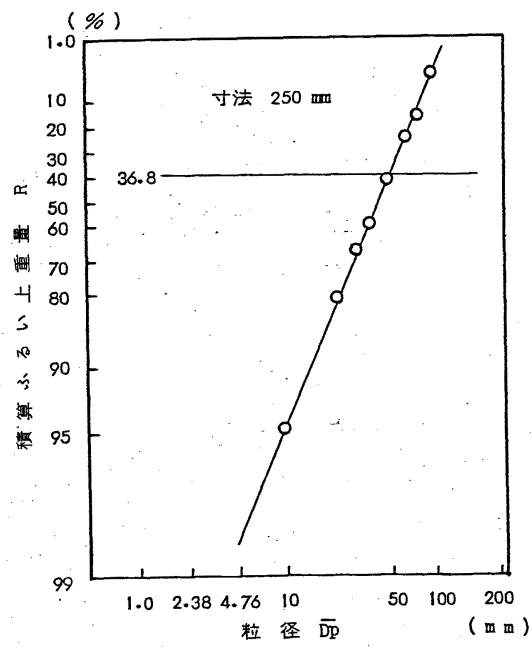

第1図

破砕産物のRosinRammler 線図

・供試体寸法 $25 \mathrm{~cm} \times 25 \times 25$

- 薬量 $8 \mathrm{~g}$

- 装薬深度 $125 \mathrm{~mm}$

多くなり，粒度範囲が狭くなり，bは破碎産物を構成する 破砕片の代表粒径の 1 種でその大小は破砕産物の粒度に関 係する。

Benne ${ }^{3)}$ は, $b=1 / D_{e}^{n}$ とおき，(1)式を

$$
R\left(D_{p}\right)=100 \cdot \exp \left\{-\left(D_{p} / D_{e}\right)^{n}\right\}
$$

とかきかえた。いま， $D_{p}=D_{e}$ とすると，

$$
R\left(D_{e}\right)=100 \cdot e^{-1} \div 36.8(\%)
$$

となる。 $D_{e}$ は $R\left(D_{p}\right)$ が $36.8 \%$ 時の破砕産物粒子群の粒 径をあたえることになり, 破砕産物の粒度特性值とよばれ, 1 種の代表径をあたえる。

(2)式を変形し，2 度対数をとると

$$
\log \left[\log \left\{100 / R\left(D_{p}\right)\right\}\right]=n \cdot \log \left(D_{p} / D_{e}\right)
$$$$
+\log \cdot \log e=n \cdot \log D_{p}+C
$$

となる。ここで $C=\log \cdot \log e-n \cdot \log D_{e}$ である。

(3)式は, 横軸に $\log D_{p}$, 縦軸に $\log \left[\log \left\{100 / R\left(D_{p}\right)\right\}\right]$ を目盛つたグラフ上で直線をあらわし， $n$ はその直線の勾 配から求められ, $D_{e}$ は $R\left(D_{p}\right)=36.8 \%$ の時, 直線のあた える $D_{p}$ の值から図式的に求められる。

いま，破砕産物をフルイ分け，その結果を上述したグラ フ上にプロットし, 直線が得られれば，その破砕産物は

Rosin-Rammler分布にしたがうとしてよく，その分布関 数をあたえる式は(1)式のようになり，その時図から得られる $D_{e}$ と $n$ を用いれば, その破砕産物の算術平均粒子径 $\overline{D_{p}}$ は

$$
\overline{D_{p}}=D_{e} \cdot \gamma(1 / n+1)
$$

\begin{tabular}{|c|c|c|c|}
\hline 寸法(mm) 一慗量 ( $\mathrm{g})$ & & 寸法(mm)一萝量 $(\mathrm{g})$ & \\
\hline $250-2$ & -0 & $157-2$ & $-\square-$ \\
\hline $250-8$ & $-0-$ & $157-6$ & $-\square-$ \\
\hline $198-2$ & $-\Delta$ & $125-2$ & 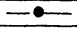 \\
\hline $198-4$ & $-\Delta-$ & $125-4$ & -0 \\
\hline
\end{tabular}

なる式により，ガンマ関数表を用い計算できる。

筆者らが行なつた実験のうち, シリーズ 1 に属し, 薬量 $8 \mathrm{~g}$ を供試体中心で起爆させた時の破挽産物のフルイ分け 結果の 1 例を第 3 表に示した。この時のRosin-Rammler

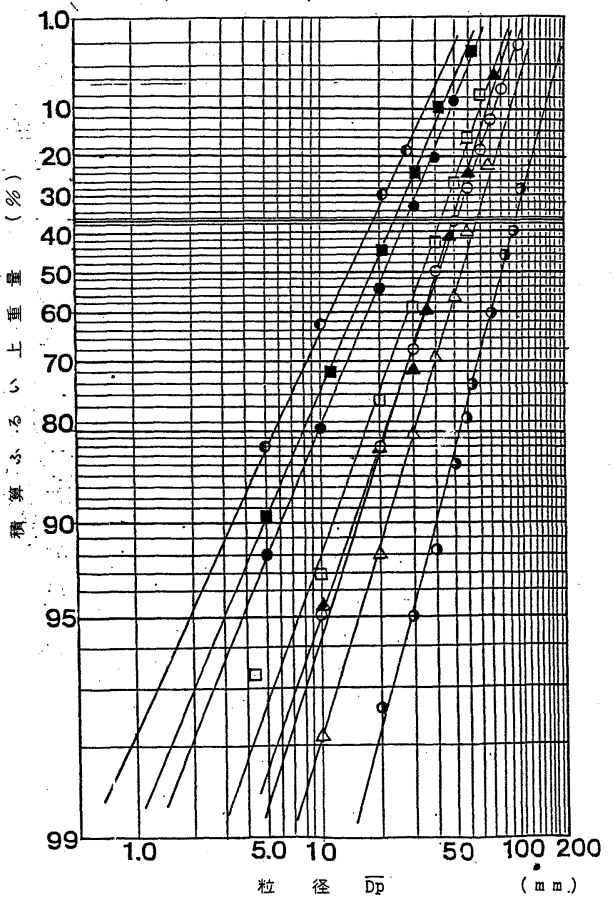

破碎産物のRosinRammler プロット の例 
のグラフに示した図 (Rosin-Rammler プロットと呼ぶ ) が第 1 図である。このほか筆者らが行なつた実験のうち, 条件の異なる 2 , 3の場合のRosin-Rammler プロット を一括して示せば第 2 図のようになる。

これらの結果は, 装薬深度が小さくなつたり, 小さな供 試体を大きな量の爆薬で破砕し, いわゆる比装薬量が大き くなつた時に点のバラッキがわずかに認められたり, 全体 として粒子径の小さい範囲で直線からの偏りも大きくなる が, 引かれた最小自乗曲線は直線と見做してもそれほど大 きな䛊差はない。すなわち，筆者らの実験で得られた破砕 産物はRosin-Ramm ler 分布にしたがい，その粒度分布 は(1)式にしたがうとしてよいことが明らかである。

\section{$3 \cdot 2$ 破砕産物の比表面積の計算}

なんらかの方法で破砕産物の表面積を計算することがで きれば，実施した爆破において使用した爆薬のもつエネル ギーが破砝に十分有効に利用されたかどうか，ひいては装 薬量の決定などにおいて導入した值が最適であつたかどう かなどの評価ができる。

筆者らの実験で，得られた破砕産物がRosin-Rammler 分布にしたがうことが明らかにされたので, 粒子群の $D_{e}$, $n$ をもとめ, 体積形状係数 $\phi_{v}$ と表面積形状係数 $\phi_{s}$ との比 としてあたえられる比表面積形状係数 $\phi\left(=\phi_{s} / \phi_{v}\right)$ を用 い, $\mathrm{Matz}^{5)}$ が $R=99.9 \%$ に相当する粒子径を下限に， $R$ $=0.1 \% に$ 相当する粒子径を上限にとつて， $n>0$ で一定 の值をとるとしてあたえた。

$$
S_{W}=\frac{\phi}{\rho_{p}} \cdot 10^{4} \cdot \frac{1}{D_{e}}\left\{r\left(1-\frac{1}{n}\right)-\frac{0.0010^{\left(1-\frac{1}{n}\right)}}{1-(1 / n)}\right.
$$

なる式によつて破砕産物の比表面積 $S_{W}\left(\mathrm{~cm}^{2} / \mathrm{g}\right)$ を計算し た。ここで， $n, D_{e}$ は前述した值であり， $\rho_{p}$ は破砕された 供試体の粒子の密度である。

二つの形状係数 $\phi_{v}$ と $\phi_{s}$ は, 破砕産物の同一粒径区分内

の粒子群から無作為に最大で 50 個ずつ抽出し, Heywood ${ }^{6}$ の方法で測定した。測定される粒子を最も安定した状態で

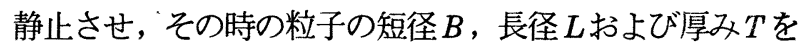
測定し, その均斉度をあらわす二つの指数, 長短度 $N=$ $L / B$ と扁平度 $m=B / T$ を求め,

$$
\begin{aligned}
\phi_{v} & =K_{e} / m \cdot \sqrt{N_{L S}} \\
\text { と } \quad \phi_{s} & =1.57+C \cdot\left(K_{e} / m\right)^{\frac{4}{3}}\left(N_{L S}+1 / N_{L S}\right) \\
& =1.57+C \cdot \phi_{v}^{\frac{4}{3}}\left\{\left(N_{L S}+1\right) / N_{L S}{ }^{\frac{1}{3}}\right\}
\end{aligned}
$$

とを用いて計算した。

筆者らの実験で得られた破砕産物の各粒径区分に属する 粒子の長短度, 扁平度, $\phi_{s}$ および $\phi_{v}$ とそれらを用いて計 算された比表面積形状係数を第 4 表に示した。計算にあた つて用いた常数 $K_{e}$ と $C$ は, Heywoodが形状がやや角張つ た粒子の時にあたえた值 ${ }^{7)} 0.51$ と2.6をそれぞれ用いた。

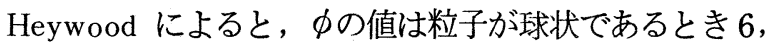
不規則形状粒子で $6.5 \sim 8$ とあたえている。第 4 表の值は， それにくらべて全体としてやや大きな值になり，特に粒子 が細かくなるほど大きな値になつている。Heywood のあ げた值が必ずしもそのままあてはまるわけではないが，筆 者らの計算で $K_{e}, C$ の値を一律に粒子全体について仮定し たり， $N, m$ の值を求める時, 粒径区分の大きい方で抽出 された個数が少なく，極端な場合には 1 個しか得られない 時もあり，測定のために抽出された破砕粒子の数が多くな つた粒度区分の小さい範用の粒子では，測定がむずかしく 誤差が大きくなつたなどが偏りの原因と考えられる。

\section{4. 結果の考察}

\section{$4 \cdot 1$ 装薬深度の変化にともなう破砕産物の粒度特性 の変化}

一辺が $250 \mathrm{~mm}$ の長さの最大寸法の供試体を用い, 薬量 $8 \mathrm{~g}$ を装薬深度を変えて起爆させた時の破砕産物について, $n, D_{e}$ および $\overline{D_{p}}$ の值を一括して第 5 表に示した。

\begin{tabular}{|c|c|c|c|c|c|c|}
\hline 粒径区分 (mm) & $\mathrm{N}$ & NLB & $\mathrm{m}$ & $\phi_{8}$ & $\phi \mathrm{V}$ & $\phi$ \\
\hline $180 \sim 170$ & 1 & $\cdot 1.03$ & 1. & 3. 13 & 0.400 & 7. 83 \\
\hline $170 \sim 160$ & 1 & 1. 34 & 1.37 & 3. 03 & 0.322 & 9. 40 \\
\hline $160 \sim 150$ & 3 & 1.09 & 1.29 & 3. 08 . & 0.377 & 8. 16 \\
\hline $150 \sim 140$ & 1 & 1. 21 & 1. 22 & 3. 22 & 0.380 & 8. 47 \\
\hline $140 \sim 130$ & 0 & & & & & \\
\hline $130 \sim 120$ & 6 & 1. 28 & 1. 27 & 3. 15 & 0.354 & 8.90 \\
\hline $120 \sim 110$ & 17 & 1. 25 & 1. 36 & 2. 94 & 0.325 & 9.06 \\
\hline $110 \sim 100$ & 28 & 1. 24 & 1. 41 & 2.96 & 0.321 & $9 \cdot 21$ \\
\hline $100 \sim 90$ & 34 & 1. 28 & 1. 36 & 2.99 & 0.327 & 9. 15 \\
\hline $90 \sim 80$ & 50 & 1.30 & 1. 42 & 2. 92 & 0.310 & 9. 40 \\
\hline $80 \sim 70$ & 50 & 1. 28 & 1. 49 & 2. 86 & 0.301 & 9. 48 \\
\hline $70 \sim 60$ & 50 & $.1 \cdot 27$ & 1. 44 & 2. 89 & 0.310 & 10.4 \\
\hline $60 \sim 50$ & 50 & . 1. 42 , & 1. 51 & 2. 87 & 0. 285 & 10.8 \\
\hline $50 \sim 40$ & 50 & 1.51 & 1. 52 & 2. 82 & 0.263 & 10. 7 \\
\hline $40 \underset{\tau}{\sim} 30$ & 50 & 1. 42 & 1. 51. & 2. 90 & 0.288 & 10. 1 \\
\hline $30 \sim 20$ & 50 & 1. 74 & 1. 56 & 2. 92 & 0.245 & 11.8 \\
\hline $20 \sim 10$ & 50 & 1.62 & 2. 61 & 2. 19. & 0.237 & 9. 25 \\
\hline $10 \sim 4.76$ & & & & & & 11.0 \\
\hline-4.76 & & & & & & 11.0 \\
\hline
\end{tabular}

その結果, 装薬位置が深くなり, 装薬重心が供試体の中

第 4 表 破研産物の長短度 $\left(N_{L S}\right)$, 扁平度 $(m)$, 表面積形状係数 $\left(\phi_{s}\right)$ 体積形状係数 $\left(\phi_{v}\right)$ および比表面積形状係数 $(\phi)$ の值 (一例)

※ $\mathrm{N} L \mathrm{~B}=$ 破砕産物の長短度, $\mathrm{m}=$ 扁平度, $\phi \mathrm{s}=$ 表面皘形状係数， $\phi_{\mathrm{v}}=$ 体皘形状係数および $\phi=$ 比表面皘形状係数の值 (一例), $\mathrm{N}=$ 破砕片の数
心に近くなるにつれて, 同じ量の爆薬で爆破 しても得られた破砕産物を構成する破砕片の $n$ や $D_{e}$ の值が小さくなり, 装薬深度が大きい と浅い処に装薬して起爆した場合にくらべて 細か心破砕片が多くなり，粒径の大きいもの から小さいものまで広い粒度範囲をとるよう になり, 全体として平均粒径が小さくなつて ゆく

筆者らの場合，供試体の大きさが限られて

\begin{tabular}{|c|c|c|c|c|c|}
\hline $\begin{array}{l}\text { 寸法 } \\
(\mathrm{mm})\end{array}$ & ( & $\begin{array}{r}\text { 深度 } \\
(\mathrm{mm})\end{array}$ & $\mathrm{De} \quad(\dot{\mathrm{m} m})$ & $n$ & $\overline{\mathrm{Dp}}(\mathrm{mm})$ \\
\hline $250-$ & 8 & -25 & 113 & 2. 38 & 100 \\
\hline $250-$ & 8 & -50 & 85 & 2. 31 & 75 \\
\hline $250-$ & 8 & -75 & 70 & 2. 10 & 62 \\
\hline $250-$ & 8 & -100 & 61 & 1. 87 & 54 \\
\hline $250-$ & 8 & -125 & 51 & 1. 78 & 46 \\
\hline
\end{tabular}
いて装薬深度をあまり大きくできなかつた上

第5表 供試体の大きさと薬量一定で装薬深度 を変えた時の実験結果 
に実験回数も十分でなかつたので, 使用した爆薬量につい て破砕産物が最小平均粒径をあたえる装薬深度をはつきり と示すことはできなかつた。しかし，構成する破砕片の粒 度の細かいものが多くなり，破砕産物全体としての平均粒 径が小さくなつたのであるから，破砕片が粗く狭い粒度範 囲に分布する破砕産物しか得られなかつた場合にくらべ爆 薬が破砕仕事に有効に利用されたといえる。

装薬深度が $25 \mathrm{~mm}$ の場合を基準にすると, その他の場合 の装薬深度は, それぞれ 2 倍, 3 倍, 4 倍および 5 倍にな つている。しかし, 破砕産物の平均粒径をみると基準の場 合を 1 とすると, それぞれ， $0.75 ， 0.62 ， 0.54$ および 0.46 と小さくなり, $n$ の值をも同時に考慮すれば, 破砕産 物を構成する破砕片の細かい粒度のものが多くなつている ことが明らかである。縦軸に平均粒径を普通尺でとり，装 薬深度を対数尺で横軸にとつて両者の関係をあらわすと第 3 図のように直線が得られる。すなわち, 装薬深度を次第 に深くしてゆくと破砕産物の平均粒径も次第に小さくなる が，それらの間にはむしろ指数関数の関係が成立つことが わかる。

これらのことから, 決つた量の爆薬を用い, 一定の大き さの岩石塊を爆破しようとするとき, 装薬深度を変えるこ とによつて破砕産物の粒度構成を変えることができ薬量が 十分であれば，装薬深度が深くなるほど破砕片の粒度は小 さくなり，破砕産物全体の平均粒径は小さくなる。しかし， その時, 使用する爆薬量によつて得られる破砕産物の平均 粒径の最小値をあたえる装薬深度が存在することがわかる。

第 3 図の平均粒径と装薬深度との関係をあらわす直線の 実験式は

$$
\overline{D_{p}}=206-33.2 \times \ln (W)
$$

となつた。

装薬が供試体の中心になされた時の深度を $W_{o}$, そのほか の場合のそれを $W$ とて, 両者の比をとり深度比 $W / W_{0}$ で

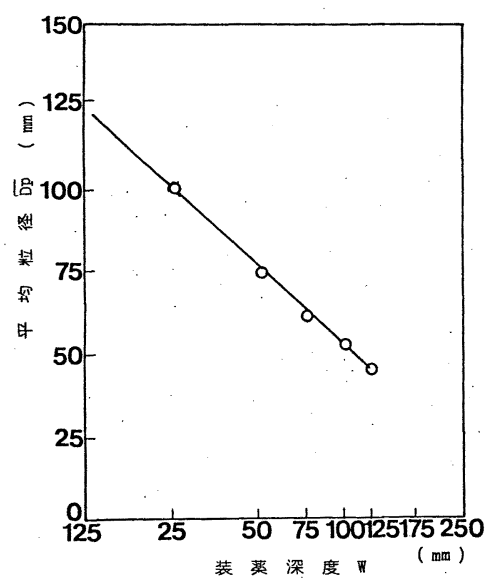

第3図装薬深度と破砕産物

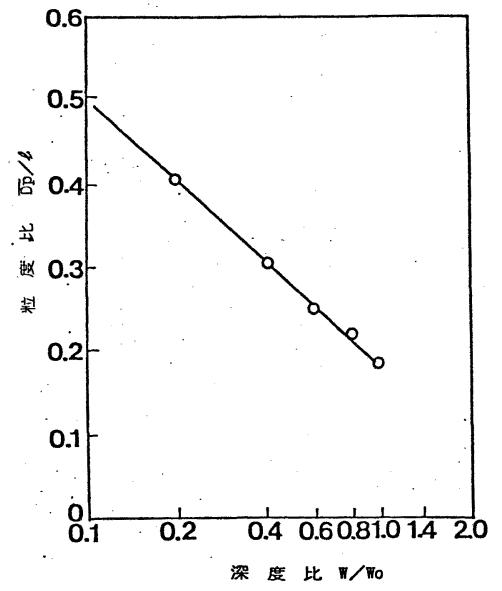

第 4 図 装薬深度比 $\left(W / W_{0}\right)$ と粒度比 $(\overline{D p} / l)$ との関係
あらわし，それぞれの装薬深度で得られた破砕産物の平均 粒径と供試体の大きさをあらわす一辺の長さ $l$ との比で粒 度比 $\overline{D_{p}} / l$ をあらわして結果を無次元化すると, 粒度比を 普通尺で縦軸にとり, 深度比を対数尺で横軸にとつてプロ ットすれば第 4 図が得られる。点の数は少ないが引かれた 最適直線からの点のバラッキがほとんどなく, これらの間 の関係は

$$
\overline{D_{p}} / l=0.713-0.143 \times \ln \left(W / W_{0}\right)
$$

となる。

\section{$4 \cdot 2$ 比装薬量の変化にともなう破砕産物の粒度特性 の変化}

爆破される供試体の単位体積あたりの使用爆薬量をあら わす比装薬量を変えるのに, 薬量を一定にして供試体の大 きさを変える場合と供試体の大きさを一定にして薬量を変 える場合とがある。

筆者らは装薬位置が供試体の中心になるようにしてその 両方の場合を実験した。それらの結果を総括したのが第 6 表である。この表の上下方向に同じ大きさの供試体をちが つた薬量で爆破した場合を示し, 左右方向に同じ薬量が大 きさの異なる供試体を爆破した場合を示した。

この表から, 薬量が一定の場合は供試体が小さくなり, また, 供試体の大きさが一定の時は薬量が大きくなつて, 比装薬量が大きくなるほど, 破砕産物を構成する破砕片の 粒度分布範囲が細か心方へ拡がり, 全体として細かく䂶か れて平均粒径が小さくなることがわかる。

いま供試体の体積を $V$ であらわし，横軸に対数目盛でと り, おのおのの平均粒径を縦軸に普通目盛でとつて, それ ぞれの薬量について両者の関係を示すと第 5 図が得られる。 この図から薬量が同じであると供試体の体積が小さくなる ほど破砕産物の平均粒径が小さくなり, 全体として細かく 砕かれるが供試体がある限度以下になると得られる破砕産 物の平均粒径が接近した值になり, 薬量のちがいに関係な

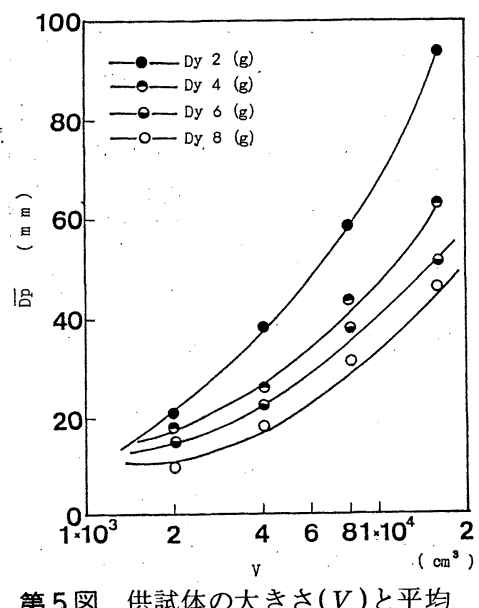

第 5 図 供試体の大きさ $(V)$
粒径 $\left(\overline{D_{p}}\right)$ との関係

第6表 供試体の大きさ, 装薬量を変えて行なつた実験の結果

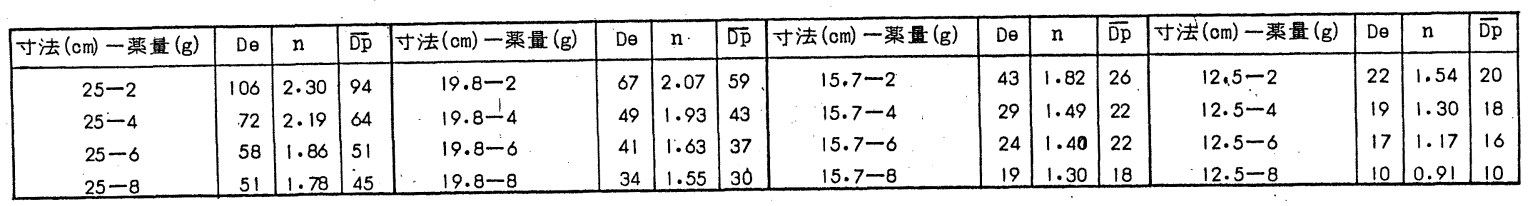




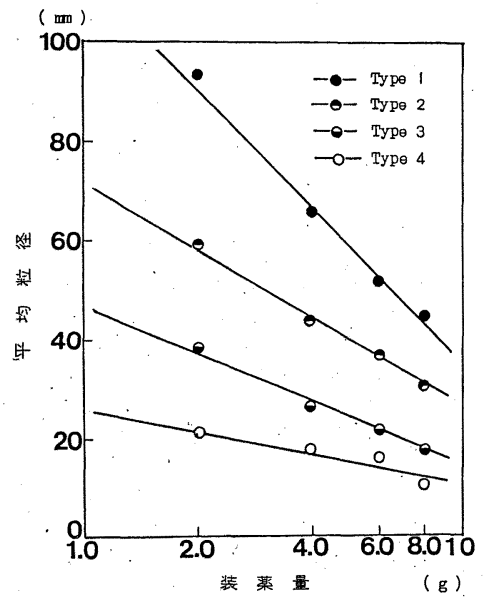

第7表 $\begin{aligned} & \text { 比装薬量 } \\
& \text { 破砕産物 }\end{aligned}$
\begin{tabular}{|l|l|}
\hline $\mathrm{L} / \mathrm{V}\left(\mathrm{kg} / \mathrm{m}^{8}\right)$ & $\mathrm{nav}$ \\
\hline 0.128 & 2.30 \\
0.256 & 2.18 \\
0.384 & 1.86 \\
0.512 & 1.84 \\
0.768 & 1.63 \\
1.02 & 1.53 \\
1.54 & 1.40 \\
2.05 & 1.30 \\
3.07 & 1.17 \\
4.10 & 0.91 \\
\hline
\end{tabular}
第6図
装薬量の変化と破砕産物
の平均粒径との関係

しに決つた平均粒径の破砕産物しか得られなくなることが わかる。

一方, 供試体の大きさを一定にして薬量を変えて比装薬 を変化させた時は, 薬量 $L$ を横軸に対数目盛でとり, 各破 砕産物の平均粒径を縱軸に普通目盛でとつて, それぞれの 大きさの供試体について両者の関係をあらわすと第 6 図が 得られる。寸法の小さい供試体で薬量が多くなるとわずか に点のバラッキが認められたが，勾配の異なる 4 本の直線 が引かれた。この場合, 直線の勾配の大きいほど薬量のわ ずかな変化で破碎産物の平均粒径が大きく変わることを示す ので，その中心に装薬して爆破を行なうとき大きな供試体 ほど比装薬量の変化が破砕産物の粒度構成に大きく影響す るといえる。

筆者らの実験をもとにして比装薬量を考えた時, 供試体 の大きさや装薬量によつては, それが同じ值になる場合が あつた。それで, 同じ比装薬量のときの破碎産物の特性値 $D_{e}, n, D_{p}$ の値を平均し, 比装薬量 $L / V$ を $\mathrm{kg} / \mathrm{m}^{3}$ の単 位であらわし，両者の関係を第 7 表に示した。

第 8 表 装薬深度比 $\left(W / W_{0}\right)$ と破砕産物 の平均比表面積 $\left(S_{W a v}\right)$ と平均比 表面積 $\left(S_{W} / S_{W_{0}}\right)_{a v}$ の値

\begin{tabular}{|c|c|c|}
\hline W/W.O & Swav & (Sw/Swo) $\mathrm{av}$ \\
\hline 0.2 & 0.707 & 6.04 \\
0.4 & 0.988 & 8.44 \\
0.8. & 1.33 & 11.4 \\
0.8 & 1.62 & 13.9 \\
1.0 & 2.23 & 19.0 \\
\hline
\end{tabular}

第9表 比装薬量 $(L / V)$ と破砕産物 の平均比表面積 $\left(S_{W a v}\right)$ と平 均比表面積比 $\left(S_{W} / S_{W o}\right)_{a v}$ の值

\begin{tabular}{|c|c|c|}
\hline $\mathrm{L} / \mathrm{V}\left(\mathrm{kg} / \mathrm{m}^{\mathrm{s}}\right)$ & Swav & (Sw/SWO) aV \\
\hline 0.128 & 0.877 & 7.50 \\
0.256 & 1.30 & 10.1 \\
0.384 & 1.88 & 16.1 \\
0.518 & 2.32 & 16.7 \\
0.768 & 3.14 & 22.0 \\
1.02 & 5.57 & 29.8 \\
1.54 & 7.50 & 42.2 \\
2.05 & 11.9 & 58.2 \\
3.07 & 21.3 & 88.8 \\
4.10 & 97.4 & 405 \\
\hline
\end{tabular}

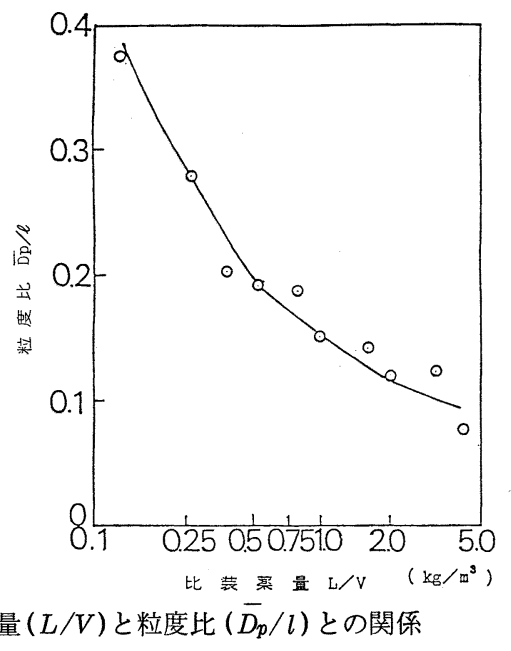

いま比装薬量を普通目盛で横軸にとり，その時の破砕産 物の平均粒径と供試体の大きさとの関係を粒度比であたえ て, 緃軸に対数目盛でとつて, それら両者の関係を示せば 第 7 図が得られる。すなわち, 比装薬量が大きくなるほど 破砕産物は細かくなるが，此装薬量がある値を越えて大き くなつても, 破砕産物はそれほど細かくならず一定の粒度 比に近づくことがわかる。

\section{$4 \cdot 4$ 破砕産物の比表面積}

一定の大きさの供試体について一定量の爆薬を異なる装 薬深度で起爆させて得た破砕産物の比表面積 $S_{W} \mathrm{~cm}^{2} / \mathrm{g}$ と 大きさが異なる供試体の中心で異なる量の爆薬を起爆させ た時の破研産物の比表面積を第 8 表と第 9 表に示した。

第 8 表では, 装薬深度の变化を装薬深度比 $W / W_{0}$ であら わし, 得られた破砕産物の比表面積の值と破碎前の供試体 の比表面積 $S_{W_{0}}$ との比, すなわち比表面積比 $S_{W} / S_{W_{0}}$ の値 とを示し, 第 9 表では, 供試体の大きさと装薬量の変化を 比装薬量 $L / V \mathrm{~kg} / \mathrm{m}^{3}$ であたえ, それぞれの場合の破砕産 物の比表面積の值と比表面積比の偩を示してある。さきに のべたように，供試体の大きさを変えた時と装薬量を変え た時とで同じ比装薬量になる場合があり, それらの場合の 結果は平均して一つの值で示した。
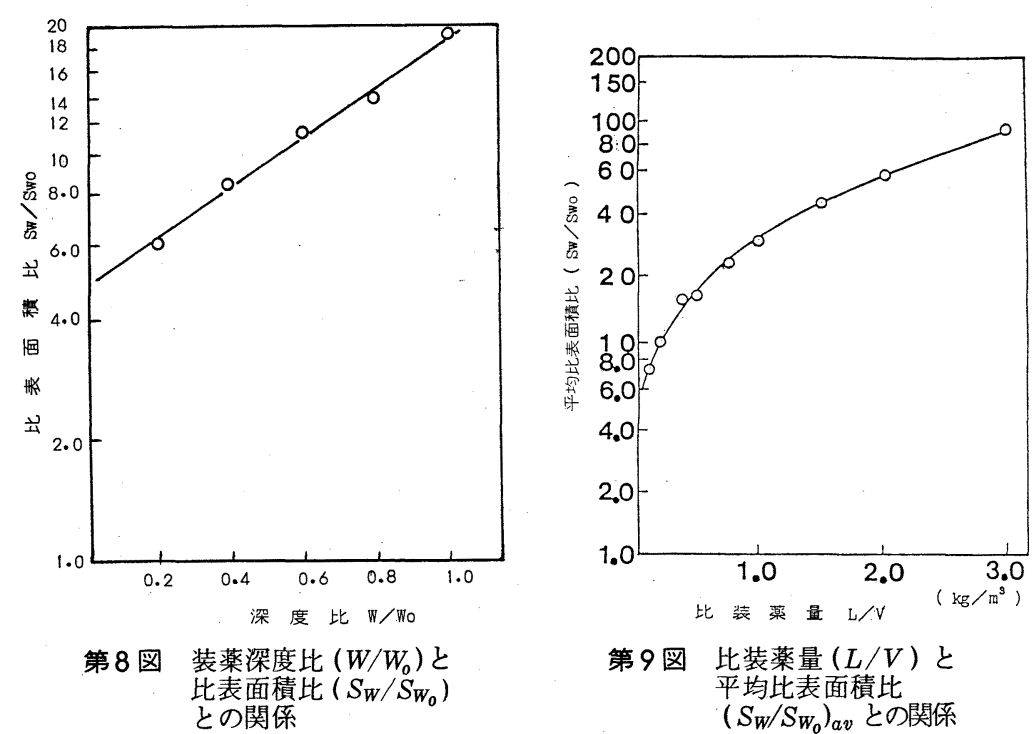

第9図比装薬量 $(L / V)$ と 平均比表面積比 $\left(S_{W} / S_{W_{0}}\right)_{a v}$ との関係 
装薬深度が大きくなり, 深度比が 1 に近づくにつれて破 砕産物の比表面積が次第に大きくなつている。この実験で は, 深度比が最小の場合の破砕産物にくらべ 1 になつたと きのそれは約 3 倍の比表面積をもつようになる。爆発して 新たな表面積を作りだすためにだけ爆薬が使われたとする と, 爆薬の量が同じでもその装薬深度のいかんによつては, 爆薬の力の $1 / 3$ ほどしか有効に利用されないこともあるこ とを示している。

縦軸に比表面積比を対数尺でとり, 横軸に深度比を普通 尺でとつて両者の関係を図示すると第 8 図になり, 引かれ た最適直線があたえる実験式は

$$
\begin{aligned}
& \frac{S_{W}}{S_{W_{0}}}=4.72 e^{140\left(\frac{W}{W_{0}}\right)} \\
& \text { となつた。 }
\end{aligned}
$$

大きな比装薬量で爆破を行なえば，供試体は細かくくだ かれ破砕産物の比表面積が増加する。その状況は第 9 表に 示したものから推測される。すなわち，比装薬量が 0.768 $\mathrm{kg} / \mathrm{m}^{3}$ 程度までは, 最小比装薬量 $0.128 \mathrm{~kg} / \mathrm{m}^{3}$ の3 倍程度 までしか比表面積が増加せず, 比装薬量の増加にくらべて 小さい。比装薬量が $4.10 \mathrm{~kg} / \mathrm{m}^{3}$ と最小值の 32 倍ほどで破 砕によつて作りだされる比表面積は 100 倍を越え, 比表面 積比も 54 倍になる。これらの結果を縦軸に比表面積比を普 通尺でとり, 横軸に比装薬量を対数尺でとつて示せば, 第 9 図の通りである。すなおち, 比装薬量が大きくなると, 爆破される前の岩石の比表面積に比較される破砕産物の比 表面積は次第に大きくなるが，比装薬量がある值を越えて 大きくなつても, その後の比表面積比の増加は目立たなく なることがわかる。
5. 結語

本研究は, 特殊な設定のもとで行なわれた実験であつた が，爆破による破砕産物の粒度分布はRosin-Rammler 分布関数であらわしうることが確かめられた。その結果, 破砕産物全体についての平均粒径や粒度分布指数, あるい は粒度分布特性数などを比較的容易に計算でき，さらには 破砕産物の比表面積も求めることができた。

発破実験は, 実験条件にかなりの注意を払つても結果の 再現性が低く, 適切な結論を導きだすことが極めて困難で あつた。この研究で明らかにされたように破砕産物の分布 特性をあらわす特徵数が容易に計算されれば， $2 ， 3$ の試 みがなされたように爆破実験の定量的比較や評価が可能で ある。

今後, 漏斗孔試験で得られる破砕産物についても同様の 方法が適用しうるかどうかを探り，より一般的で合理的な 発破設計のための基準值を見いだすことに努めたい。

実験にあたつては, 工学士安部善嗣君と工学士古澤明夫 君等の絶大な助力を得た。

1）大塚・宮腰・佐藤らによる“岩石爆破に関する基礎的研究” と題す る日本鉱業会春季大会講演

2）たとえば, G. HERDAN "SMALL PARTICLE STATISTICS" pp. $121 \sim 124$

3) Bennet, J. G. : J. Inst.Fuel . 10, 22 39, (1936)

4）たとえば, G. HERDAN：上掲

5) 井伊谷鋼一編：粉体工学ハンドブック, 朝倉書店（1965） pp. $50 \sim 51$

6）同 上,,$\quad$ pp. $54 \sim 61$

7）同上, p. 61

\section{Size Distribution Characteristics of Fragments by Blasting}

\section{_ Fundamental study on rock blasting}

by Kazuo OTSUKA ${ }^{1}$, Hiroshi MIYAKOSHI ${ }^{2}$, Hiroshi $\mathrm{SATO}^{3}$, Isamu $\mathrm{SATO}^{4}$ and Hajime IWAI $^{5}$

Fixing our eyes upon the size distribution characteristics of fragments by blasting, we made experiments on crushing of uniform size cubic blocks which are made of cement mortar. The results obtained with the good reproducibility are as follows,

1) Rosin-Rammlar-Bennt diagrams of all blasting fragments were made of straight lines, so we admitted that the size distribution of fragments may be characterized by Rosin-Rammlar distribution function.

2) With constants which were found from lines for each fragment, namely the size distribution constant $(n)$ and the absolute size constant $(D e)$, we calculated mean particle size $(D p)$ and specific surface area $(S w)$ through

$$
\begin{aligned}
& \overline{D_{p}}=D_{e} \gamma\left(\frac{1}{n}+1\right) \\
& S_{w}=\frac{\phi}{\rho_{p}} \cdot 10^{4} \cdot \frac{1}{D_{e}}\left\{\gamma\left(1-\frac{1}{n}\right)-\frac{0.0010\left(1-\frac{1}{n}\right)}{1-\left(\frac{1}{n}\right)}\right.
\end{aligned}
$$

where $\phi=$ specific shape factor of crushing products which are given surface shape factor $(\phi s)$ and volume shape factor $(\phi v)$ through Heywood's method, $\rho_{p}=$ density of crushed particles.

3) From optimum straight line through our experimental data, we found out following formulas,

a) The relation between the mean particle size and charge depth $(W)$.

$$
\overline{D_{p}}=206-33.2 \cdot I_{n} W
$$

b) The relation between the specific surface area ratio and charge depth one,

$$
\frac{S_{N}}{S_{W_{0}}}=4.72 e^{1.40\left(\frac{W}{W_{0}}\right)}
$$

where $S_{W_{0}}=$ specific surface area of original block, $W_{0}=$ max. charge depth, distance of center of block.

$$
\begin{aligned}
& \text { 1. Prof., Dr., Mining College, Akita Univ. } \\
& \text { 3. Lecturer, Mining College, Akita Univ. } \\
& \text { 5. Mining College, Akita Univ. (at present, Mitsui Coal Co., Ltd.) }
\end{aligned}
$$

2. Assoc. Prof., Mining College, Akita Univ. 4. Mining College, Akita Univ. 